\title{
Oxygen and temperature effect on continuous citric acid secretion in Candida oleophila
}

\author{
Savas Anastassiadis* \\ Pythia Institute of Biotechnology \\ Environmental Engineering Department \\ Democritus University of Thrace \\ Vat. \#: 108851559 \\ Avgi/Sohos, 57002 Thessaloniki, Greece \\ Tel: 302395051324 \\ Tel/Fax: 302395051470 \\ E-mail: sanasta@env.duth.gr \\ Hans-Jürgen Rehm \\ Institute of Molecular Microbiology and Biotechnology \\ University of Münster \\ Corrensstr. 3, 48149 Münster, Germany \\ (retired Professor) \\ Website: http://www.greekbiotechnologycenter.gr
}

\begin{abstract}
Financial support: Part of the work that has been carried out at the Institute of Biotechnology 1 of Research Centre Jülich (Germany) was financed by
\end{abstract} Haarmann and Reimer, a daughter company of the company Bayer, Leverkusen, Germany.

Keywords: Candida oleophila, citric acid, citric acid secretion.

Abbreviations: $\mathrm{m}_{\mathrm{p}}$ :Specific productivity of the generic product, $\mathrm{g}$ product $/(\mathrm{g}$ biomass $\mathrm{x} h)$

$\mathrm{R}_{\mathrm{j}}$ : Volumetric productivity of the generic product, g product/(1 $\left.\mathrm{xh}\right)$

RT: Residence time, hrs

Rs: Volumetric glucose consumption rate, $\mathrm{g} /(1 \mathrm{x}$ h)

The influence of air saturation and temperature on continuous citric acid secretion was studied in chemostat cultures of Candida oleophila ATCC 20177 (var.). Simultaneous measurements of intra- and extracellular concentration of glucose, citric and isocitric acid confirmed the involvement of a specific active transport system in citrate secretion, favouring citric acid over isocitrate. An optimum air oxygen saturation of $20 \%$ and temperature of $30-31^{\circ} \mathrm{C}$ were determined for the continuous citric acid secretion. The highest values of citric acid concentration (98 $\mathrm{g} / \mathrm{L}$ ), citrate to isocitrate ratio (33.3:1), volumetric citric productivity (1.8 $\mathrm{g} /(\mathrm{L} \times \mathrm{X}))$, and specific citric acid productivity $(0.1 \mathrm{~g} /(\mathrm{g} \times \mathrm{h}))$, were reached at $20 \%$ air saturation at a residence time of 54 hrs by the experiment's lowest biomass of $18 \mathrm{~g} / \mathrm{L}$. The highest isocitic acid volumetric productivity $(55.6 \mathrm{mg} /(\mathbf{L} \times \mathbf{h}))$ and specific productivity $\left(0.99 \mathrm{mg} /\left(\begin{array}{lll}(\mathrm{g} & \mathrm{x} & \mathrm{h}\end{array}\right)\right)$ were identified at $50 \%$, instead. The fastest citrate excretion rate of the generic product of $0.046 \mathrm{~g} /\left(\mathrm{g}^{*} \mathrm{~h}\right)$ was found at $30-31^{\circ} \mathrm{C}$. A concentration ratio between extra- and intracellular concentration of citrate of up to 9 was identified. The highest extra-/intracellular ratio of citrate and lowest intracellular concentrations of glucose, citric and isocitric acid were determined at optimum air saturation as a consequence of active citrate export.

Citric acid is a tricarboxilic organic acid of industrial importance (Naumenko et al. 2004), which is produced by fermentation using almost exclusively improved strains of the fungus Aspergillus niger in aerobe bioreactors (Saha and Takahashi, 1997; Wieczorek and Brauer, 1997; Wieczorek and Brauer, 1998). The simultaneous synthesis of citric, isocitric (undesirable by-product) and other organic acids by yeasts was extensively studied (Akiyama et al. 1973a; Akiyama et al. 1973b; Anastassiadis, 1994; Moresi, 2004; Grewal and Kalra, 1995; Anastassiadis et al. 1993; Anastassiadis et al. 1994; Anastassiadis et al. 2001; Crolla and Kennedy, 2001; Kamzolova et al. 2003; Crolla and Kennedy, 2004; Venter et al. 2004), in particular by using strains of Yarrowia spp. and Candida spp. under shake flasks, batch or fed batch, continuous repeated batch, continuous repeated fed batch or chemostat fermentation conditions (Tabuchi et al. 1970; Lozinov and Finogenova, 1982; Rupcic et al. 1996; Chernyavskaya et al. 2000; Crolla

\footnotetext{
* Corresponding author
} 
and Kennedy, 2001; Papanikolaou and Aggelis, 2002; Morgunov et al. 2004; Anastassiadis and Rehm, 2005; Anastassiadis and Rehm, 2006).

Previous studies have demonstrated the feasibility of a semi-continuous production of citric acid by $A$. niger (Lesniak and Stawicki, 1979). An efficient continuous production of citric acid remained however for long time an unachievable dream. A multi-tank system was suggested for the continuous operation using $A$. niger, which would separate growth phase and idiophase from each other. This would essentially require higher investments and efforts, making a commercial production uneconomical (Lockwood, 1979; Milson, 1987; Crueger and Crueger, 1989; Klasson et al. 1989; Saha and Takahashi, 1997; Wieczorek and Brauer, 1997; Wieczorek and Brauer, 1998). Continuous single-stage operations using A. niger yielded low citric acid concentrations (Kristiansen and Sinclair, 1979; Saha and Takahashi, 1997; Wieczorek and Brauer, 1997; Wieczorek and Brauer, 1998). The main actual problems at citric acid industry today are the still low productivities of discontinuous $A$. niger processes, requiring long operational times, higher investments and production costs, compared with the novel yeast processes (Legisa and Gradisnik-Grapulin, 1995; Anastassiadis et al. 2001; Kumar et al. 2003; Kurbanoglu, 2004; Kurbanoglu and Kurbanoglu, 2004; Ikram-ul et al. 2004; Ali and Ikramul, 2005; Anastassiadis and Rehm, 2005). Wieczorek and Brauer (1997) reported about slowing down of continuous citric acid formation by $A$. niger in a reciprocating-jetbioreactor at increasing fermentation time (more than 20 days), still without achieving of steady state conditions. Continuous operations for the production of citric acid by yeasts have increasingly received research interest in last years. However, the yields were insufficient for an economically competitive industrial operation (Enzminger and Asenjo, 1986; Kim et al. 1987; Kim and Roberts, 1991; Klasson et al. 1989; Bubbico et al. 1996; Arzumanov et al. 2000; Anastassiadis et al. 2005; Anastassiadis and Rehm, 2005).

Citric acid production takes places under growth limiting conditions (Crueger and Crueger, 1989; Grewal and Kalra, 1995; Anastassiadis et al. 2001; Anastassiadis et al. 2002; Anastassiadis et al. 2005; Anastassiadis and Rehm, 2006). The microbial system must be rigid enough, in order to withstand the sheerness and to resist against the stress conditions occurring during the long time continuous operation of chemostat cultures. Long sporulation times are necessary before the inoculation of the small inoculum bioreactor and thereafter of the larger production bioreactor. For this reason, A. niger is unsuitable for an efficient continuous operation using free growing cells without any biomass retention. However, in contrary to yeasts $A$. niger can also convert sucrose by invertase (Hossain et al. 1984; Milson, 1987). Because of the above indicated inadequacies and problems, Candida oleophila ATCC 20177 (var.) was identified during an extensive screening under many yeast strains (Anastassiadis, 1994; Anastassiadis et al. 2001; Anastassiadis et al. 2002), enabling the development of new continuous fermentation processes, which would stand today's strong competition in citric acid industry (Anastassiadis, 1994; Anastassiadis et al. 1993; Anastassiadis et al. 1994; Anastassiadis et al. 2001; Anastassiadis et al. 2005; Anastassiadis and Rehm, 2005; Anastassiadis and Rehm, 2006). C. oleophila offers a good alternative for a continuous operation of citric acid production. Initially, only $10 \mathrm{~g} / \mathrm{L}$ of citric acid were produced in preliminary continuous experiments by $C$. oleophila. $150 \mathrm{~g} / \mathrm{L}$ and a formation rate for the generic product $(\mathrm{Rj})$ of $2 \mathrm{~g} /(\mathrm{L} \times \mathrm{h})$ were reached after an extensive process development program carried out in chemostat (Anastassiadis et al. 1993; Anastassiadis et al. 1994; Anastassiadis et al. 2001; Anastassiadis and Rehm, 2005; Anastassiadis and Rehm, 2006). 210-250 g/L citric acid [Rj of up to $5 \mathrm{~g} /(\mathrm{L} \times \mathrm{h})]$ have been continuously produced within 56-120 hrs in repeated batch experiments by a Yarrowia lipolytica strain at the Research in Biotechnology, Greece, (data not shown here). A. niger is difficult to handle, because of its multicellular mycelial growth behaviour, causing clogging problems. The use of yeasts instead of moulds represents an innovative approach, which is also of human health. In contrary to yeast Candida oleophila, A. niger possesses the formation potential of toxic compounds (micotoxins) (Anastasssiadis et al. 2005).

A little information exists in international bibliography regarding the mechanism of citric acid secretion in yeasts and fungi and the excretion mechanism of citrate from cytoplasm into the medium in A. niger still remains unclear (Grewal and Kalra, 1995; Netik et al. 1997; Anastassiadis and Rehm, 2005; Anastassiadis and Rehm, 2006). Looking at the literature, no results were found about the effect of oxygen and temperature on the continuous citric acid

Table 1. Temperature influence on the steady citric acid production continuous process. Chemostat was operated at a dilution $\mathrm{D}$ $=0.018 \mathrm{~h}^{-1}\left(3 \mathrm{~g} / \mathrm{L} \mathrm{NH}{ }_{4} \mathrm{Cl}, 240 \mathrm{~g} / \mathrm{L}\right.$ glucose, $\left.\mathrm{pH} 4.5\right)$.

\begin{tabular}{|c|c|c|c|c|c|c|}
\hline Temp. & [Citrate] & {$[$ Isocitrate] } & Ratio & [Biomass] & Rcitrate & $\mathbf{m}_{\text {citrate }}$ \\
\hline${ }^{\circ} \mathrm{C}$ & $(\mathrm{g} / \mathrm{l})$ & $(\mathrm{g} / \mathrm{l})$ & & $(\mathrm{g} / \mathrm{l})$ & {$[\mathrm{g} /(\mathrm{l} \times \mathrm{h})]$} & {$[\mathrm{g} /(\mathrm{g} \times \mathrm{h})]$} \\
\hline $\mathbf{2 4}$ & 12.00 & 0.58 & 17.0 & 8.00 & 0.15 & 0.019 \\
\hline $\mathbf{2 7}$ & 22.67 & 1.09 & 20.9 & 11.2 & 0.28 & 0.025 \\
\hline $\mathbf{2 9}$ & 43.14 & 2.53 & 17.1 & 20.3 & 0.54 & 0.027 \\
\hline $\mathbf{3 0}$ & 63.54 & 2.21 & 28.8 & 17.4 & 0.79 & 0.046 \\
\hline $\mathbf{3 1}$ & 60.63 & 2.97 & 20.4 & 16.5 & 0.76 & 0.046 \\
\hline
\end{tabular}


formation and secretion by free growing yeast cells. The intracellular accumulation and secretion of citric acid are obviously two different phenomena, which influence each other in a very complicated manner. A high specific active transport system for citric acid secretion has been detected for the first time in Candida oleophila based on simultaneous intra- and extracellular steady state measurements of citric and isocitric acid, glucose and the ATP/ADP ratio in the cells. It is acting as the speed determining factor well explaining overproduction of citric acid against a concentration gradient (Anastassiadis et al. 1993; Anastassiadis, 1994; Anastassiadis et al. 1994; Anastassiadis et al. 2001; Anastassiadis and Rehm, 2005; Anastassiadis and Rehm, 2006). Netik et al. (1997) reported later about a $\Delta \mathrm{pH}$-driven $\mathrm{H}^{+}$-symport dependent system for citric acid export in manganese-deficient cells of A. niger. They claimed that only a passive diffusion over the plasma membrane had been reported before for citrate excretion in yeasts in accordance with reports of Marchal et al. (1980) and McKay et al. (cited in Gutierrez and Maddox, 1993). For a very long time it has been thought that a continuous citric acid production using free growing cells wasn't feasible. Additionally, no information existed about the influence of air saturation on the continuous citric acid secretion and a little was known regarding the real effect of oxygen on the continuous citrate formation.

The central aspect of present work was to investigate the effect of important fermentation parameters, such as air saturation and temperature on the continuous secretion of citric acid by a specific active transport system in $C$. oleophila ATCC 20177 (var.).

\section{MATERIALS AND METHODS}

\section{Microorganism}

Candida oleophila, strain ATCC 20177 (var.) was used, which was obtained from Dr. Siebert, Jungbunzlauer Co. and from Haarmann and Reimer (Bayer Co affiliated company, Leverkusen, Germany) was used. This strain was selected in previous studies under many yeast strains (Anastassiadis, 1994). Yeast malt extract agar plates (YME) inoculated with C. oleophila were incubated for 2-3 days and stored at $4^{\circ} \mathrm{C}$. Cultures were refreshed every 2-3 months. Glycerine cultures ( $30 \%$ glycerine) were frozen at -20 or $-80^{\circ} \mathrm{C}$ and stock cultures were lyophilized as well.

\section{Apparatus}

The influence of temperature on continuous citric acid fermentation was investigated in 1 litter glass bioreactor (Research Center Jülich, Germany) at $1000 \mathrm{rpm}$ and an aeration rate of $4 \mathrm{l} / \mathrm{min}$ pure oxygen for a working volume of $460 \mathrm{ml}$ (corresponds to $0.145 \mathrm{vvm}$ ). Pure oxygen was used in order to satisfy the low oxygen transfer in small glass fermenter (Anastassiadis et al. 2005). The effect ofoxygen on continuous citric acid fermentation was investigated in a 2 litter bioreactor (Biostat E, Braun-
Diessel) at a working volume of $1.91,600 \mathrm{rpm}, \mathrm{pH} 4.5$ and $30^{\circ} \mathrm{C}$. The air saturation (\%) was measured and controlled as has been described in Anastassiadis et al. 2001 and Anastassiadis et al. 2005. This setting of air saturation control was found to be best solution for keeping constant air saturation over a very long period of time. The air saturation was adjusted to $100 \%$ using atmospheric air at 1 vvm flow rate, $1000 \mathrm{rpm}$ agitation, $30^{\circ} \mathrm{C}$ and $\mathrm{pH} 4.5$ in sterilized fermentation medium. The $0 \%$ air saturation value was adjusted using $1 \mathrm{vvm}$ nitrogen gas.

\section{Media}

The inoculum $(10 \%)$ was prepared by transferring cells from agar plates into $500 \mathrm{ml}$ shake flasks with buffles on a medium containing BM medium with $3 \mathrm{~g} / \mathrm{L} \mathrm{NH}_{4} \mathrm{Cl}$ and 30 $\mathrm{g} / \mathrm{L}$ glucose. The shake flasks were incubated for 1 day at $30^{\circ} \mathrm{C}$ and $200 \mathrm{rpm}$. A basal medium (BM) was used for the investigation of temperature effect containing: $3 \mathrm{~g} / \mathrm{L}$ $\mathrm{NH}_{4} \mathrm{Cl}, 240 \mathrm{~g} / \mathrm{L}$ glucose, $0.7 \mathrm{~g} / \mathrm{L} \mathrm{KH}_{2} \mathrm{PO}_{4}, 0.35 \mathrm{~g} / \mathrm{L} \mathrm{MgSO}$ x $7 \mathrm{H}_{2} \mathrm{O}, 0.11 \mathrm{~g} / \mathrm{L} \mathrm{MnSO}_{4} \mathrm{x} 4 \mathrm{H}_{2} \mathrm{O}, 0.002 \mathrm{~g} / \mathrm{L}^{\mathrm{CuSO}_{4}} \mathrm{x}$ $5 \mathrm{H}_{2} \mathrm{O}, 0.021 \mathrm{~g} / \mathrm{L} \mathrm{ZnSO}_{4} \times 7 \mathrm{H}_{2} \mathrm{O}, 0.004 \mathrm{~g} / \mathrm{L} \mathrm{CoSO}_{4} \times 7 \mathrm{H}_{2} \mathrm{O}$, $0.04 \mathrm{~g} / \mathrm{L} \mathrm{H}_{3} \mathrm{BO}_{3}, 0.1 \mathrm{~g} / \mathrm{L} \mathrm{CaCl} 2,0.1 \mathrm{~g} / \mathrm{L} \mathrm{NaCl}, 0.0001 \mathrm{~g} / \mathrm{L}$ $\mathrm{KJ}, 2.5 \mathrm{~g} / \mathrm{L}$ citric acid, $0.0002 \mathrm{~g} / \mathrm{L} \mathrm{Na}_{2} \mathrm{MoO}_{4} \times 2 \mathrm{H}_{2} \mathrm{O}, 0.002$ $\mathrm{g} / \mathrm{L}$ Thiamine-HCl, $0.00025 \mathrm{~g} / \mathrm{L}$ Biotin, $0.000625 \mathrm{~g} / \mathrm{L}$ Pyridoxine- $\mathrm{HCl}, 0.000625 \mathrm{~g} / \mathrm{L}$ Ca-D-Pantothenate, 0.0005 $\mathrm{g} / \mathrm{L}$ Nicotinic acid. An optimized medium was used for the investigation of oxygen influence containing: $250 \mathrm{~g} / \mathrm{L}$ glucose, $4.5 \mathrm{~g} / \mathrm{L} \quad \mathrm{NH}_{4} \mathrm{Cl}, 1.05 \mathrm{~g} / \mathrm{L} \quad \mathrm{KH}_{2} \mathrm{PO}_{4}, 0.525 \mathrm{~g} / \mathrm{L}$ $\mathrm{MgSO}_{4} \times 7 \mathrm{H}_{2} \mathrm{O}, 0.2507 \mathrm{~g} / \mathrm{L} \mathrm{MnSO}_{4} \times 4 \mathrm{H}_{2} \mathrm{O}, 0.00015 \mathrm{~g} / \mathrm{L}$ $\mathrm{CuSO}_{4} \times 5 \mathrm{H}_{2} \mathrm{O}, 0.0315 \mathrm{~g} / \mathrm{L} \mathrm{ZnSO}_{4} \times 7 \mathrm{H}_{2} \mathrm{O}, 0.006 \mathrm{~g} / \mathrm{L}$ $\mathrm{CoSO}_{4} \times 7 \mathrm{H}_{2} \mathrm{O}, 0.06 \mathrm{~g} / \mathrm{L} \mathrm{H}_{3} \mathrm{BO}_{3}, 0.15 \mathrm{~g} / \mathrm{L} \mathrm{CaCl}_{2}, 0.15 \mathrm{~g} / \mathrm{L}$ $\mathrm{NaCl}, 0.00015 \mathrm{~g} / \mathrm{L} \mathrm{KJ}, 2.5 \mathrm{~g} / \mathrm{L}$ citric acid, $0.0003 \mathrm{~g} / \mathrm{L}$ $\mathrm{Na}_{2} \mathrm{MoO}_{4} \times 2 \mathrm{H}_{2} \mathrm{O}, 0.003 \mathrm{~g} / \mathrm{L}$ Thiamine-HCl, $0.000375 \mathrm{~g} / \mathrm{L}$ Biotin, $0.0009375 \mathrm{~g} / \mathrm{L}$ Pyridoxine-HCl, $0.0009375 \mathrm{~g} / \mathrm{L}$ CaD-Pantothenate, $0.00075 \mathrm{~g} / \mathrm{L}$ Nicotinic acid. Vitamins and $\mathrm{NH}_{4} \mathrm{Cl}$ were added separately into autoclaved medium (30$60 \mathrm{~min}$ at $121^{\circ} \mathrm{C}$ ) by sterile filtration through $0.2 \mu \mathrm{m}$ filters (Sartorius filter, Göttingen Germany). No $\mathrm{Fe}^{+2}$ salt has been intentionally added in to the media. Silicon oil or polypropylene glycol was used as antifoaming agent. In all cases, nitrogen was a limiting factor of yeast growth. The culture flow rate $\mathrm{D}$ was $0.0185 \mathrm{~h}^{-1}$.

\section{Chemostat experiments}

The temperature was maintained automatically at $30^{\circ} \mathrm{C}$ and the $\mathrm{pH}$ at 4.5 by the automatic titration of $45 \% \mathrm{NaOH}$ solution. The $\mathrm{pO}_{2}$ level was maintained within $5-133 \%$ of saturation. The experiments were carried out as has been described in Anastassiadis and Rehm, 2005 and Anastassiadis and Rehm, 2006. Fermentation data presented here didn't result from just only one single measurement. They represent an average of several measurements attained after achieving steady state conditions during a period of several days. In generally, between five and 10 generations (residence times, RT) were necessary for achieving steady state conditions at each of air saturation levels. When the flow rate and fermentation 
Table 2. Intracellular concentration of critical metabolites (glucose, citrate and isocitrate), and intra- (i) and extracellular (e) ratios between the citrate species as a function of temperatures.

\begin{tabular}{|c|c|c|c|c|c|c|c|c|c|}
\hline & \multicolumn{5}{|c|}{ Intracellular concentration } & \multicolumn{4}{|c|}{ Ratios } \\
\hline Temp & Citrate & Isocitrate & Glucose & $\begin{array}{c}\text { Citrate } \\
+ \\
\text { Isocitrate }\end{array}$ & $\begin{array}{c}\text { Citrate } \\
+ \\
\text { Isocitrate } \\
+ \\
\text { Glucose }\end{array}$ & $\begin{array}{l}\text { Citrate/ } \\
\text { Citrate }\end{array}$ & $\begin{array}{l}\text { Isocitrate/ } \\
\text { Isocitrate }\end{array}$ & $\begin{array}{l}\text { Citrate/ } \\
\text { Isocitrate }\end{array}$ & $\begin{array}{c}\text { Citrate/ } \\
\text { Isocitrate }\end{array}$ \\
\hline$\left({ }^{\circ} \mathrm{C}\right)$ & $(\mathrm{mg} / \mathrm{g})$ & $(\mathrm{mg} / \mathrm{g})$ & $(\mathrm{mg} / \mathrm{g})$ & $(\mathrm{mg} / \mathrm{g})$ & $(\mathrm{mg} / \mathrm{g})$ & (e/i) & $(\mathrm{e} / \mathrm{i})$ & $(\mathrm{i} / \mathrm{i})$ & $(\mathrm{e} / \mathrm{e})$ \\
\hline 27 & 21.6 & 90.6 & 2.6 & 112.2 & 114.8 & 2.4 & 0.03 & 0.24 & 20.9 \\
\hline 29 & 10.2 & 54.3 & 45.8 & 64.5 & 110.3 & 9.3 & 0.10 & 0.19 & 17.1 \\
\hline 31 & 19.8 & 25.9 & 0 & 45.7 & 45.7 & 6.7 & 0.25 & 0.76 & 20.4 \\
\hline
\end{tabular}

parameters had achieved a stationary level, the cultivation in each mode was continued until the culture medium in bioreactor was replaced five times. There was no difference in experimental data obtained under the same operation conditions in dependence of starting randomly or not a new chemostat experiment from a new Agar plaque or continuing last fermentation.

\section{Analysis}

Optical density $\left(\mathrm{OD}_{660 \mathrm{~nm}}\right)$ and dry biomass (filter method) were measured as described (Anastassiadis et al. 2002). Organic acids, glucose, ammonia nitrogen and intracellular concentrations were analyzed as described in Anastassiadis, 1993; Anastassiadis, 1994; Anastassiadis et al. 1993; Anastassiadis et al. 1994; Anastassiadis et al. 2001; Anastassiadis et al. 2002; and Anastassiadis et al. 2005.

\section{Intracellular measurements of citric and isocitric acid and glucose}

Intracellular concentrations of citric, isocitric acid and glucose were precisely evaluated using the above HPLC methods (High Pressure Liquid Chromatography) after their extraction following the procedure as has been described in Anastassiadis and Rehm, 2005 and Anastassiadis and Rehm, 2006.

\section{Residual nitrogen}

The residual nitrogen was measured as has been described in Anastassiadis et al. (2002), however no nitrogen was detected in all of experiments.

\section{RESULTS}

\section{The effect of temperature on continuous citric} acid secretion by $C$. oleophila

The influence of temperature on citric acid production by C. oleophila was investigated in chemostat experiments at a residence time of about $80 \mathrm{hrs}$ and $\mathrm{pH} 4.5 .20$ days were necessary for achieving steady state conditions after the temperature was increased from 27 to $29^{\circ} \mathrm{C}$. The highest citrate concentration of $63.5 \mathrm{~g} / \mathrm{L}$, citrate/isocitrate ratio of
28.8 and formation rate of the generic product $(\mathrm{Rj})$ of 0.8 $\mathrm{g} /(\mathrm{L} \mathrm{x} \mathrm{h})$ were achieved at $30^{\circ} \mathrm{C}$, compared with only 12 $\mathrm{g} / \mathrm{L}(18.9 \%), 17$ and $0.15 \mathrm{~g} /(\mathrm{L} \mathrm{x} \mathrm{h})$ found at $24^{\circ} \mathrm{C}$. The highest specific citric acid productivity of $0.046 \mathrm{~g} /(\mathrm{g} \mathrm{x} \mathrm{h})$ was determined at $30-31^{\circ} \mathrm{C}$. The highest biomass concentration (X) of $20.3 \mathrm{~g} / \mathrm{L}$ was measured at $29^{\circ} \mathrm{C}$. Isocitric acid concentration increased with the exception of $30^{\circ} \mathrm{C}(2.21 \mathrm{~g} / \mathrm{L})$ at raising temperature (Table 1$)$. Only 80 $\mathrm{g} / \mathrm{L}$ of citric acid was achieved at a RT of more than 100 at $30^{\circ} \mathrm{C}$ under still sub-optimal fermentation conditions. The intracellular steady state concentrations of citrates and glucose were determined at selected temperatures. Intracellular isocitric acid concentration decreased drastically with increasing temperature reaching $10.2 \mathrm{mg} / \mathrm{g}$ dried biomass at $31^{\circ} \mathrm{C}$. In contrary, citric acid concentration remained roughly constant, indicating in accordance to previous studies (Anastassiadis and Rehm, 2005) that a minimum concentration is required for functioning of active transport system. Thus, a greater intracellular ratio between citrate and isocitrate is to record at higher temperatures, which is still lower than 1 , in contrary to an almost identical extracellular ratio (Table 2). An intracellular glucose concentration of $2.6 \mathrm{mg} / \mathrm{g}$ was identified at $27^{\circ} \mathrm{C}$ and of $45.8 \mathrm{mg} / \mathrm{g}$ at $29^{\circ} \mathrm{C}$ (Table 2).

\section{The effect of oxygen on continuous citric acid secretion by $C$. oleophila}

The effect of air saturation on continuous citric acid secretion by $C$. oleophila was examined at a residence time around $55 \mathrm{hrs}$, applying an optimised chemostat medium, optimum temperature of $30^{\circ} \mathrm{C}$ and $\mathrm{pH}$ 4.5. Citric acid secretion has been found to be strongly influenced by air saturation, resulting at $54 \mathrm{hrs}$ residence time $(\mathrm{D}=0.0185$ $\mathrm{h}^{-1}$ ) to maximum values of $98 \mathrm{~g} / \mathrm{L}$ citric acid, $70 \%$ molar selectivity (Mol citrate/Mol glucose), $1.81 \mathrm{~g} /\left(\begin{array}{lll}\mathrm{L} & \mathrm{x} & \mathrm{h}\end{array}\right)$ formation rate of the generic product $\left(\mathrm{R}_{\mathrm{f}}\right), 0.1 \mathrm{~g} /(\mathrm{g} \times \mathrm{h})$ specific citric acid productivity $\left(\mathrm{m}_{\mathrm{p}}\right)$ of and 33.3 ratio between citrate and isocitrate (3\% isocitrate) at the optimum saturation of $20 \%$. Only $71.4 \mathrm{~g} / \mathrm{L}$ citric acid (72.6\%) was produced at $133 \%$ and $77.2 \mathrm{~g} / \mathrm{L}(78.6 \%)$ at $5 \%$. Hereby, the experiment's lowest biomass of $18 \mathrm{~g} / \mathrm{L}$ was measured at $20 \%$ compared with $29.6 \mathrm{~g} / \mathrm{L}$ found at $80 \%$. The maximum $\mathrm{Rj}$ of $55.6 \mathrm{mg} /(\mathrm{L} \times \mathrm{h})$ for isocitric acid was identified at $50 \%$ and $\mathrm{m}_{\mathrm{p}}$ of $2.9 \mathrm{mg} /(\mathrm{g} \mathrm{x} \mathrm{h})$ at $20 \%$. The very high ratio found between citrate and isocitrate, which 
corresponds to $\mathrm{m}_{\mathrm{p}}($ citrate $) / \mathrm{m}_{\mathrm{p}}$ (isocitrate) ratio, specifies the high affinity of active transport system towards citric and over isocitric acid, claiming a specificity maximum at $20 \%$ saturation. The highest glucose consumption rate of 2.6 $\mathrm{g} /(\mathrm{L} \times \mathrm{h})$ was specified at $78 \%$ air saturation, whereas specific glucose consumption rate reached a maximum of $0.13 \mathrm{~g} /(\mathrm{g} \mathrm{x} \mathrm{h})$ at $20 \%$. Citrate concentrations of up to 150 $\mathrm{g} / \mathrm{L}$ have been achieved under the same fermentation conditions at longer RT using C. oleophila (Anastassiadis, 1994; Anastassiadis et al. 1993; Anastassiadis et al. 1994; Anastassiadis et al. 2001).

In contrary to highest extracellular citric acid values, the lowest intracellular isocitrate concentration of $24.4 \mathrm{mg} / \mathrm{g}$ dry biomass, citrate + isocitrate of $53.1 \mathrm{mg} / \mathrm{g}(125.6 \mathrm{mM})$, glucose of $17.6 \mathrm{mg} / \mathrm{g}(8 \mathrm{~g} / \mathrm{L}$ or $44.4 \mathrm{mM})$ or total acid plus glucose concentration of $70.72 \mathrm{mg} / \mathrm{g}$ and the highest intracellular ratio between citrate and isocitrate of 1.18 were determined at optimum air saturation of $20 \%$. In comparison, a total intracellular acid concentration (citrate plus isocitrate) of $135.9 \mathrm{mg} / \mathrm{g}$ ( $256 \%$ compared with $20 \%)$ and total acid + glucose concentration of $163.2 \mathrm{mg} / \mathrm{g}$ $(230.8 \%)$ were determined at $5 \%$ and $96.8 \mathrm{mg} / \mathrm{g}(182.3 \%)$ and $123.1 \mathrm{mg} / \mathrm{g}(174.1 \%)$ at $133 \%$ saturation. The lowest intracellular citrate concentration of about $9.5 \mathrm{mg}$ citrate $/ \mathrm{g}$ dried biomass (corresponds to $4.3 \mathrm{~g} / \mathrm{L}$ or $22.5 \mathrm{mM}$ ) was determined at $29 \%$ compared with $28.7 \mathrm{mg} / \mathrm{g}(13.1 \mathrm{~g} / \mathrm{L}$ or $67.96 \mathrm{mM})$ or $53.63 \mathrm{mg} / \mathrm{g}(20.7 \mathrm{~g} / \mathrm{L}$ or $107.58 \mathrm{mM})$ measured at $20 \%$ or $5 \%$, respectively. With exception of $20 \%$ a higher intracellular concentration of isocitrate has been found along the entire range of air saturation compared with citrate (intracellular ratio between citrate and isocitrate was lower than 1). Comparing the intracellular citrate/isocitrate ratio of 1.18 with the extracellular ratio of 33.3 found a very high citrate secretion rate becomes obviously at $20 \%$ that drives out isocitrate from aconitase equilibrium towards citrate. A concentration ratio of 7.5 was calculated at $20 \%$ between extra- and intracellular citric acid, based on measured extracellular concentration of $98 \mathrm{~g} / \mathrm{l}$ and the determined intracellular citrate concentration of $13.1 \mathrm{~g} / \mathrm{L}$ or $67.96 \mathrm{mM}$.

\section{DISCUSSION}

There are only a few reports related to the continuous production of citric acid. Kinetic data for growth and production from continuous chemostat cultures offer very important information for process development, optimization and scale up. Present work describes for the first time the very significant effect of oxygen and temperature on continuous production and secretion of citric acid using free growing cells of Candida oleophila. In comparison, most of the reported works regarding citric acid fermentation were carried out without any oxygen measurement and control.

\section{Temperature effect}

Significant differences and different optimum temperatures were determined for growth and production in mesophilic yeast $C$. oleophila, although they are somehow coupled to each other. C. oleophila grows and produces in good agreement with literature reports for the discontinuous citric acid fermentation by yeasts (Rane and Sims, 1993; Crolla and Kennedy, 2001) at temperatures between 24 and $31^{\circ} \mathrm{C}$, displaying an optimum temperature of $30-31^{\circ} \mathrm{C}$. Temperatures lower than $27^{\circ} \mathrm{C}$ slowed down growth and production substantially. Tabuchi (1973) noted growth and citrate production in C. lipolytica even at $35^{\circ} \mathrm{C}$ using glucose medium, whereas no growth took place in paraffin medium. Intracellular analysis data of present work confirmed in a good agreement with previous data regarding the continuous citrate secretion through a high specific $\mathrm{pH}$-dependent active transport system in yeasts (Anastassiadis et al. 1993; Anastassiadis, 1994; Anastassiadis et al. 1994; Anastassiadis et al. 2001; Anastassiadis and Rehm, 2005; Anastassiadis and Rehm, 2006). A higher glucose uptake rate, glucose consumption through the glycolysis and citrate secretion rate is proposed at optimum temperatures, based on the very low intracellular concentrations of glucose, citric and isocitrate acid. The specific productivity $\left(\mathrm{m}_{\mathrm{p}}\right)$, which corresponds to the secretion rate, is the best parameter to choose in order to identify, whether there is any possible connection between the intracellular concentration of citrates and their secretion rate. A 3.5-fold intracellular isocitrate concentration was found at $27^{\circ} \mathrm{C}$ and a 2.1 -fold at $29^{\circ} \mathrm{C}$ compared with $31^{\circ} \mathrm{C}$, which is 1.7 times higher at $27^{\circ} \mathrm{C}$ compared with $29^{\circ} \mathrm{C}$ $(3.5 / 2.1=1.7)$. For comparison, 2.67 times higher citric acid was produced at $31^{\circ} \mathrm{C}$ compared with $27^{\circ} \mathrm{C}$, and 1.41 times higher compared with $29^{\circ} \mathrm{C}(2.67 / 1.41=1.9)$. Intracellular concentration of isocitric acid is directly influenced by active transport system, reversely revealing extracellular concentration of citric acid in almost the same proportion. The speed of removal of intracellular isocitric acid from aconitase equilibrium towards citrate and citrate secretion reflects the transport system's activity. The lowering of citrate excretion by specific active transport system would consequentially result in the accumulation of isocitrate and glucose in cytoplasm. In contrary, intracellular citrate showed less fluctuation and a certain minimum concentration of about $20 \mathrm{mM}$ is necessary for the proper functioning of active transport system. A 17.6fold higher glucose concentration was found at $27^{\circ} \mathrm{C}$ compared with $29^{\circ} \mathrm{C}$, meaning a much higher glucose consumption rate at $29^{\circ} \mathrm{C}$, again as a consequence of active transport system's activity. Lapujade et al. (1999) found a similar effect of temperature on the secretion of glutamic acid in Corynebacterium glutamicum, reporting about the highest secretion at $40^{\circ} \mathrm{C}$ and the lowest intracellular glutamate accumulation. Enzyme activities as well as regulation and transport systems are in generally affected enormously by the temperature in microbial systems.

\section{Oxygen effect}

The intensity of citric acid secretion has been shown to be strongly influenced by air saturation under batch, repeated batch and continuous cultivation of $C$. oleophila, indicating the importance of oxygen demand and oxygen mass 
transfer (Anastassiadis and Rehm, 2005; present results). It had a remarkable effect on growth, citric acid accumulation, ratio between citrate and isocitrate and product yield, displaying a sharp production optimum in chemostat cultures at $20 \%$ in contrary to highest biomass found at $80 \%$. Batch and continuous repeated batch process claimed a higher productivity and selectivity at $80 \%$ saturation instead (Anastassiadis and Rehm, 2006). Citric acid production by yeasts and fungi is an obligatory aerobic process, strongly depending on the oxygen supply and air saturation in bioreactor. Most of published works in literature were carried out at unknown air saturation or dissolved oxygen concentration. In present work the air saturation was controlled, enabling the reproduction of results in further future studies. Excess of oxygen is necessary during entire fermentation, whereby even short time interruptions of oxygen supply can cause irreversible changes or a complete production lost (Rehm, 1980; Anastassiadis, 1994; Grewal and Kalra, 1995; Sakurai et al. 1996; Crolla and Kennedy, 2004). Optimum air saturations higher than $50 \%$ and up to 60 ppm (equals to about $800 \%$ air saturation) were reported in literature for discontinuous citric acid production by yeasts (Stottmeister et al. 1981; Stottmeister et al. 1986; Okoshi et al. 1987).

The very high extracellular citrate/isocitrate ratio, the very low intracellular citrate/isocitrate ratio (excepted of $20 \%$ air saturation lower than 1) and the insignificant variations of isocitrate concentration found along the entire range of air saturation indicated the high specificity of active transport system towards citrate over isocitrate. In this context it is worthy to mention that specific citric and isocitric productivity corresponds to the secretion rate of active transport system. The formation rate of the citric acids is the compensation result between biomass formation and specific productivity. The lowest intracellular concentration of glucose, isocitrate, citrate plus isocitrate, total acid plus glucose, maximum intracellular citrate/isocitrate ratio and the highest extracellular citric acid concentration were found at optimum air saturation of $20 \%$ as a result of most intensive secretion and consequentially glycolysis rate. The high glycolysis rate is possibly resulting in very high ATP levels (higher energy charge) thus intensifying citrate secretion by active transport system as has been reported in Anastassiadis and Rehm (2005). A kind of a Crabtree effect could occur in this case, simulating an anaerobic glycolytic pathway under aerobic conditions. The higher intracellular isocitrate accumulation found at suboptimal air saturations (e.g. $7 \%$ and $29 \%$ ) as a result of lower active secretion of citrate is possibly caused by the lower energy charge, indicating a higher aconitase activity. This would mean an inhibition of aconitase by ATP in contrary to AMP, which activates the enzyme, aiming the gain of energy through the respiratory chain. Dissolved oxygen concentration appears to play a very important role in terms of influencing the activity of glycolysis and respiration chain. Lower air saturation would promote ATP formation by substrate phosphorylation along the glycolysis, whereas at higher air saturation ATP synthesis would be essentially regenerated by the respiratory chain phosphorylation.

The existence of specific active transport system for citrate secretion and the strong correlation between ATP/ADP ratio and the formation rate of the generic product citrate found in C. oleophila (Anastassiadis, 1994; Anastassiadis and Rehm, 2005) goes well together with reports of Lozinov and Finogenova (1982) about the existence of a non-phosphorylating alternative oxidase found in yeasts that completes electron flow without ATP regeneration competing with the production of citric acid. Active citric acid producing strains showed lower alternative oxidase activity, instead (Lozinov and Finogenova, 1982). Whether the energy charge is the driving force for citrate excretion in A. niger is still unclear. In contrast to yeasts an active non-phosphorylating alternative oxidase has been discussed in relation with the overproduction of citric acid in A. niger (Wallrath et al. 1991). In this case, reduction equivalents are regenerated by the alternative oxidase, rather than by ATP formation. Meyrath (1967) has discussed on the other side the energy demand for growth and citrate excretion in stationary cells of $A$. niger. A significant amount of energy is required since the acid is excreted against a concentration gradient.

Iron appears to have a significant interacting influence in this content, compensating the oxygen effect by responses of cellular metabolism. Kamzolova et al. (2003) found for example a strong dependence of oxygen requirements for yeast growth and citric acid synthesis on the iron concentration in medium. Increasing iron concentration was found to result in higher biomass concentration following up Michaelis's Menden kinetics, whereas iron limitation promoted citric acid secretion by C. oleophila (Anastassiadis, 1994; Anastassiadis et al. 2001; Anastassiadis et al. 2002). The iron effect has been reported to be related to the activity of mitochondrial aconitase and other TCA cycle enzymes (Oexle et al. 1999), acting as a cofactor. Knowingly, based of the legendary reports of Akiyama et al. (1973a) and Akiyama et al. (1973b) aconitase activity has been considered abroad in literature to directly influence citric acid accumulation in yeasts. Analyzing present results it appears that the iron effect on citrate secretion is more complex and it is also related to its influence on respiratory activities. In these terms, iron limitation forces a higher glycolytic activity, which is resulting in excessive formation of ATP and subsequently to higher citric acid secretion by active transport system. In excess of iron and carbon source, even under nitrogen limitation, citric acid is broken down to smaller molecules, whilst ATP is used for the formation of biomass instead of lipids (lipogenous yeasts) or citric acid (non-lipogenous yeast) (Anastassiadis and Rehm, 2005). Energy consuming fatty acid synthesis and citric acid secretion can be considered as a means of cutting down energy overload and surplus amount of $\mathrm{NAD}(\mathrm{P}) \mathrm{H}_{2}$. Isocitric acid could somehow interact with ATP and AMP and regulate both, aconitase and transport system activity, thus also explaining its very low affinity to the transport system. This means, 
that a higher dissolved oxygen concentration is necessary under iron limitation for an efficient respiratory activity and biomass formation. Cellular metabolism at lower oxygen concentrations is supported by a higher iron concentration in medium (Kamzolova et al. 2003). 10-fold higher fluxes of pyruvate into the tricarboxylic acid cycle branch and 20 times greater TCA cycle fluxes has been reported by Hua and Shimizu (1999) for cells of Torulopsis glabrata, grown at dissolved oxygen higher than $10 \%$ compared with $1 \%$.

Previous studies have demonstrated a low-rate fed-batch and continuous production of citric acid under nitrogenlimiting conditions by the yeast Candida lipolytica or other Candida strains (Aiba and Matsuoka, 1979; Kim et al. 1987; Klasson et al. 1989; Tisnadjaja et al. 1996; Crolla and Kennedy, 2004). About a four stage process has been reported by Wieczorek and Brauer (1998) for the continuous citric acid production using $A$. niger and recirculation of fermentation broth. In comparison, present results for the continuous production of citric acid by free growing cells are the best that have been published in international bibliography. Significant citric acid concentrations have also been reached by Kamzolova et al. (2003). $98 \mathrm{~g} / \mathrm{L}$ and $125 \mathrm{~g} / \mathrm{L}$ citric acid were continuously produced by $C$. oleophila in chemostat cultures at about 54 hrs RT and up to $150 \mathrm{~g} / \mathrm{L}$ citric acid at higher RT (even 200 $\mathrm{g} / \mathrm{L}$ using a $Y$. lipolytica strain, unpublished data). $170 \mathrm{~g} / \mathrm{L}$ were reached in continuously operating repeated batch experiments by C. oleophila (Anastassiadis, 1994; Anastassiadis et al. 1993; Anastassiadis et al. 1994; Anastassiadis et al. 2001; Anastassiadis and Rehm, 2005; Anastassiadis and Rehm, 2006) and $250 \mathrm{~g} / \mathrm{L}$ by a $Y$. lipolytica strain. $250 \mathrm{~g} / \mathrm{L}$ were produced in continuous mode in fed batch experiments using C. oleophila.

\section{CONCLUDING REMARKS}

Citric acid fermentation is a very complex process. Numerous events including growth limitations, enzyme activities, energy gain and energy state, intracellular acid accumulation, as well as uptake and transport systems display different optima and regulation mechanisms, which are somehow interconnected and interrelated in a synergistic mode. The active transport system is the main speed-determining factor in citrate overproduction by yeasts. Isocitrate doesn't seem to be a high-affine substrate for the active transport system. In contrary to previous thoughts, the active transport system is regulating the intracellular accumulation of citric acid and its secretion, rather than aconitase activity. Present results for continuous citric acid production by free growing cells are the best that have been published in international bibliography. The effect of air saturation was significant, which would also influence the costs of an industrial fermentation process enormously.

\section{ACKNOWLEDGEMENTS}

We thank Professor Dr. U. Stottmeister, Mrs. E. Weissbrodt (UFZ Ctr. Envtl. Res. Leipzig-Halle, Germany) and Prof.
Dr. Christian Wandrey (Institute of Biotechnology 2 of Research Center Jülich, RCJ, Germany) for their helpful advices and support.

\section{REFERENCES}

AIBA, S. and MATSUOKA, M. Identification of metabolic model: citrate productionfrom glucose by Candida lipolytica. Biotechnology and Bioengineering, 1979, vol. 21, p. 1373-1386.

AKIYAMA, S.-I.; SUZUKI, T.; SUMINO, Y.; NAKAO, $\mathrm{Y}$. and FUKUDA, H. Induction and citric acid productivity of fluoroacetate-sensitive mutant strains of Candida lipolytica. Agricultural and Biological Chemistry, 1973a, vol. 37 , no. 4 , p. 879-884.

AKIYAMA, S.-I.; SUZUKI, T.; SUMINO, Y.; NAKAO, Y. and FUKUDA, H. Relationship between aconitate hydratase activity and citric acid productivity in fluoroacetate-sensitive mutant strain of Candida lipolytica. Agricultural and Biological Chemistry, 1973b, vol. 37, no. 4, p. 885-888.

ALI, Sikander and IKRAM-UL, Haq. Role of different additives and metallic micro minerals on the enhanced citric acid production by Aspergillus niger MNNG-115 using different carbohydrate materials. Journal of Basic Microbiology, February 2005, vol. 45, no. 1, p. 3-11.

ANASTASSIADIS, Savas. Determination of organic acids, especially citric acid and isocitric acid, in fermentation solutions and fruit juices. In: HPLC Applications, MACHEREY-NAGEL GmbH \& Co. KG (Dóren, Germany), 1993, Application no. 8, p. 4.

ANASTASSIADIS, Savas; AIVASIDIS, Alexander and WANDREY, Christian. Fermentationsverfahren zur kontinuierlichen Citronensäuregewinnung (Process for the continuous production of citric acid by fermentation), German Patent No. P 4317 488.4-09, March 181993, 1993.

ANASTASSIADIS, Savas. Zymotiki methodos gia tin sinechi paragogi tou kitrikou oxeos; Process for the continuous production of citric acid by fermentation. Greek Patent No. 940100098, February 24 1994, 1994.

ANASTASSIADIS, Savas; AIVASIDIS, Alexander and WANDREY, Christian. Fermentationsverfahren zur kontinuierlichen Citronensäuregewinnung. (Process for the continuous production of citric acid by fermentation). Austrian Patent No. 473/94, July 3 1994, 1994.

ANASTASSIADIS, Savas; AIVASIDIS, Alexander and WANDREY, Christian. Process for the continuous production of citric acid by fermentation. US Patent No. 
08/208,123, August 3 1994, 2001.

ANASTASSIADIS, Savas; AIVASIDIS, Alexander and WANDREY, Christian. Citric acid production by Candida strains under intracellular nitrogen limitation. Applied Microbiology Biotechnology, October 2002, vol. 60, no. 12, p. 81-87.

ANASTASSIADIS, Savas; WANDREY, Christian and REHM, Hans-Jürgen. Continuous citric acid fermentation by Candida oleophila under nitrogen limitation at constant $\mathrm{C} / \mathrm{N}$ ratio. World Journal of Microbiology and Biotechnology, July 2005, vol. 21, no. 5, p. 695-705.

ANASTASSIADIS, Savas and REHM, Hans-Jürgen. Continuous citric acid secretion by a high specific $\mathrm{pH}$ dependent active transport system in yeast Candida oleophila ATCC 20177. Electronic Journal of Biotechnology [online]. 15 August 2005, vol. 8, no. 2. Available from internet: http://ejbiotechnology.info/content/vol8/issue2/full/11/inde x.html. ISSN 0717-3458.

ANASTASSIADIS, Savas and REHM, Hans-Jürgen. Citric acid production from glucose by yeast Candida oleophila ATCC 20177 under batch, continuous and repeated batch cultivation. Electronic Journal of Biotechnology [online]. 15 January 2006, vol. 9, no. 1. Available from internet: http:/www.ejbiotechnology.info/content/vol9/issue1/full/5/ index.html. ISSN 0717-3458.

ARZUMANOV, Tigran E.; SIDOROV, Igor A.; SHISHKANOVA, Nadezhda $\mathrm{V}$. and FINOGENOVA, Tatyana V. Mathematical modeling of citric acid production by repeated batch culture. Enzyme and Microbial Technology, June 2000, vol. 26, no. 9-10, p. 826833.

BUBBICO, R.; LO PRESTI, S.; BRAVI, M.; MORESI, M. and SPINOSI, M. Repeated batch citrate production by Yarrowia lipolytica using yeast recycling by cross-flow microfiltration. Agro-Food Industry Hi-Tech, 1996, vol. 7, no. 2 , p. 35-38.

CHERNYAVSKAYA， O.G.; SHISHKANOVA, N.V.; IL'CHENKO, A.P. and FINOGENOVA, T.V. Synthesis of $<$ alpha $>$-ketoglutaric acid by Yarrowia lipolytica yeast grown on ethanol. Applied Microbiology and Biotechnology, February 2000, vol. 53, no. 2, p. 152-158.

CROLLA, A. and KENNEDY, K.J. Optimization of citric acid production from Candida lipolytica Y-1095 using nparaffin. Journal of Biotechnology, July 2001, vol. 89, no. 1, p. 27-40.

CROLLA, A. and KENNEDY, K.J. Fed-batch production of citric acid by Candida lipolytica grown on $n$-paraffins. Journal of Biotechnology, May 2004, vol. 110, no. 1, p. 7384.

CRUEGER, W. and CRUEGER, A. Organische Säuren. In: Biotechnologie, Lehrbuch der angewandten Mikrobiologie, Oldenbourg Verlag GmbH, München, Wien, 1989, chapter 8, p. 127-141. ISBN 3-486-28403-7.

ENZMINGER, J.D. and ASENJO, J.A. Use of cell recycle in the aerobic fermentative production of citric acid by yeast. Biotechnology Letters, January 1986, vol. 8, no. 1, p. 7-12.

GREWAL, H.S. and KALRA, K.L. Fungal production of citric acid. Biotechnology advances, 1995, vol. 13, no. 2, p. 209-234.

GUTIERREZ, N.A. and MADDOX, I.S. Evidence that impaired citrate transport into the cell is a contributory factor to extracellular citrate accumulation by a strain of Candida quilliermondii. Applied Microbiology and Biotechnology, 1993, vol. 39, no. 4-5, p. 604-608.

HOSSAIN, M.; BROOKS, J.D. and MADDOX, I.S. The effect of the sugar source on citric acid production by Aspergillus niger. Applied Microbiology and Biotechnology, June 1984, vol. 19, no. 6, p. 393-397.

HUA, Qiang and SHIMIZU, Kazuyuki. Effect of dissolved oxygen concentration on the intracellular flux distribution for pyruvate fermentation. Journal of Biotechnology, February 1999, vol. 68, no. 2-3, p. 135-147.

IKRAM-UL, H.; ALI, S.; QADEER, M.A. and IQBAL, J. Citric acid production by selected mutants of Aspergillus niger from cane molasses. Bioresource Technology, June 2004, vol. 93, no. 2, p. 125-130.

KAMZOLOVA, S.V.; SHISHKANOVA, N.V.; MORGUNOV, I.G. and FINOGENOVA, T.V. Oxygenrequirements for growth and citric acid production of Yarrowia lipolytica. FEMS Yeast Research, 2003, vol. 3, no. 2, p. 217-222.

KIM, E.K.; AMBRIANO, J.R. and ROBERTS, R.S. Vigorous stationary phase fermentation. Biotechnology and Bioengineering, October 1987, vol. 30, no. 6, p. 805-808.

KIM, E.K. and ROBERTS, R.S. Rate equations for the vigorous stationary phase fermentation of citric acid by Saccharomycopsis lipolytica. Biotechnology and Bioengineering, April 1991, vol. 37, no. 10, p. 985-988.

KLASSON, T.K.; CLAUSEN, E.C. and GADDY, J.C. Continuous fermentation for the production of citric acid 
from glucose. Applied Biochemistry and Biotechnology, 1989, vol. 20-21, p. 491-505.

KRISTIANSEN, B. and SINCLAIR, C.G. Production of citric acid in continuous culture. Biotechnology and Bioengineering, 1979, vol. 21, no. 2, p. 296-315.

KUMAR, D.; JAIN, V.K.; SHANKER, G. and SRIVASTAVA, A. Citric acid production by solid state fermentation using sugarcane bagasse. Process Biochemistry, July 2003, vol. 38, no. 12, p. 1731-1738.

KURBANOGLU, Esabi Basaran. Enhancement of citric acid production with ram horn hydrolysate by Aspergillus niger. Bioresource Technology, March 2004, vol. 92, no. 1, p. 97-101.

KURBANOGLU, Esabi Basaran and KURBANOGLU, Namudar I. Ram horn peptone as a source of citric acid production by Aspergillus niger, with a process. Journal of Industrial Microbiology and Biotechnology, July 2004, vol. 31, no. 6, p. 289-294.

LAPUJADE, Pascale; GOERGEN, Jean-Louis and ENGASSER, Jean-Marc. Glutamate excretion as a major kinetic bottleneck for the thermally triggered production of glutamic acid by Corynebacterium glutamicum. Metabolic Engineering, July 1999, vol. 1, no. 3, p. 255-261.

LEGISA, M. and GRADISNIK-GRAPULIN, M. Sudden substrate dilution induces a higher rate of citric acid production by Aspergillus niger. Applied and Environmental Microbiology, July 1995, vol. 61, no. 7, p. 2732-2737.

LESNIAK, W. and STAWICKI, S. Semi-continuous fermentation of citric acid by submerged fermentation. Acta Alimentaria Polinica, 1979, vol. 29, no. 4, p. 365-376.

LOCKWOOD, L.B. Production of organic acids by fermentation. In: PEPPLER, H.J. and PERLMAN, D. eds. Microbial Technology. Academic press, New York, 1979, vol. 1, chapter 11, p. 355-387.

LOZINOV, A.B. and FINOGENOVA, T.V. Einfluß der limitation des wachstums von hefen auf den oxidativen stoffwechsel und die produktsynthese. Acta Biotechnologica, 1982, vol. 2, no. 4, p. 317-324.

MARCHAL, R.; METCHE, M. and VANDECASTEELE, J.P. Intracellular concentrations of citric and isocitric acids in cultures of the citric acid-excreting yeast Saccharomycopsis lipolytica grown on alkanes. Journal of General Microbiology, 1980, vol. 116, p. 535-538.

MEYRATH, J. Citric acid production. Process
Biochemistry, 1967, vol. 2, no.56, p. 25-27.

MILSON, P.E. Organic acid fermentation, especially citric acid. Food Biotechnology, 1987, vol. 1, no. 2, p. 273-307.

MORESI, Mauro. Effect of glucose concentration on citric acid production by Yarrowia lipolytica. Journal of Chemical Technology and Biotechnology, 2004, vol. 60, no. 4, p. 387-395.

MORGUNOV, Igor G.; KAMZOLOVA, Svetlana V.; PEREVOZNIKOVA, Oksana A.; SHISHKANOVA, Nadezda V. and FINOGENOVA, Tatiana V. Pyruvic acid production by a thiamine auxotroph of Yarrowia lipolytica. Process Biochemistry, July 2004, vol. 39, no. 11, p. 14691474.

NAUMENKO, L.F.; BUNEEVA, N.M; KORNEEVA, R.N.; SELEMENEV, V.F. and NEMTSEV, D.V. Determination of citrate ions by potentiometric titration with a copper-selective electrode in monitoring the production of citric acid. Journal of Analytical Chemistry, March 2004, vol. 59, no. 3, p. 291-295.

NETIK, Angela; TORRES, Nestor V.; RIOL, Jose-Maria and KUBICEK, Christian P. Uptake and export of citric acid by Aspergillus-niger is reciprocally regulated by manganese ions. Biochimica et Biophysica Acta Biomembranes, June 1997, vol. 1326, no. 2, p. 287-294.

OKOSHI, H.; SATO, S.; MUKATAKA, S. and TAKAHASHI, J. Citric acid production by Candida tropicalis under high dissolved oxygen concentrations. Agricultural and Biological Chemistry, 1987, vol. 51, no. 1, p. 257-258.

OEXLE, Horst; GNAIGER, Erich and WEISS, Günter. Iron-dependent changes in cellular energy metabolism: influence on citric acid cycle and oxidative phosphorylation. Biochimica et Biophysica Acta Bioenergetics, November 1999, vol. 1413, no. 3, p. 99-107.

PAPANIKOLAOU, Seraphim and AGGELIS, George. Lipid production by Yarrowia lipolytica growing on industrial glycerol in a single-stage continuous culture. Bioresource Technology, March 2002, vol. 82, no. 1, p. 4349.

RANE, Kishore D. and SIMS, Kevin A. Production of citric acid by Candida lipolytica Y 1095: Effect of glucose concentration on yield and productivity. Enzyme and Microbial Technology, August 1993, vol. 15, no. 8, p. 646651.

REHM, H.-J. Industrielle Mikrobiologie, 2. Aufl., Springer Verlag, Berlin, Heidelberg, New York, 1980. 
RUPCIC, J.; BLAGOVIC, B. and MARIC, V. Cell lipids of the Candida lipolytica yeast grown on methanol. Journal of Chromatography A., November 1996, vol. 755, no. 1, p. 75-80.

SAHA, Mihir Lal and TAKAHASHI, Fujio. Continuous citric acid fermentation by magnetic rotating biological contactors using Aspergillus niger AJ 117173. Journal of Fermentation and Bioengineering, 1997, vol. 84, no. 3, p. 244-248.

SAKURAI, A.; IMAI, H. and SAKAKIBARA, M. Effect of oxygen tension on citric acidproduction by surface culture. Journal of Fermentation and Bioengineering, 1996, vol. 82 , no. 5, p. 519-521.

STOTTMEISTER, U.; BEHRENS, U. and GÖHLER, W. Einfluß des Sauerstoffpartialdrucks auf die Citronensäuresynthese durch Saccharomycopsis lipolytica aus $n$-Paraffinen. Zeitschrift für Allgemeine Mikrobiologie, 1981, vol. 21, no. 9, p. 677-687.

STOTTMEISTER, U.; BEHRENS, U.; WEISSBRODT, E.; WEIZENBECK, E.; DÜRESCH, R.; KAISER, M.; NÖLTE, D.; RICHTER, H.-P.; SCHMIDT, J.; KOCHMANN, W.; MAY, U.; KREIBICH, G. and SCHÖPPE, G. Patentschrift DD 239610 A1, 1986.

TABUCHI, T.; TANAKA, M.; TAHARA, Y. and ABE, M. Studies on organic acid fermentation in yeasts. Part V. Production of citric acid from $n$-paraffins by yeasts (Nippon Nogei Kagaku Kaishi). Journal Agricultural Chemical Society of Japan, 1970, vol. 44, p. 562-566.

TABUCHI, T. Relationships between citrate fermentation and cell propagation in Candida lipolytica. Nihon-nogeikagaku-kaishi (Tokyo). Journal Agricultural Chemical Society of Japan, 1973, vol. 47, p. 479-484.

TISNADJAJA, Djadjat; GUTIERREZ, Noemi A. and MADDOX, Ian S. Citric acid production in a bubblecolumn reactor using cells of the yeast Candida guilliermondii immobilized by adsorption onto sawdust. Enzyme and Microbial Technology, October 1996, vol. 19, no. 5, p. 343-347.

WALLRATH, J.; SCHMIDT, M. and WEISS, $\mathrm{H}$. Concomitant loss of respiratory chain NADH: Ubiquinone reductase (complex I) and citric acid accumulation in Aspergillus niger. Applied Microbiology and Biotechnology, 1991, vol. 36, p.76-81.

WIECZOREK, S. and BRAUER, H. Continuous production of citric acid with recirculation of the fermentation broth after product recovery; Part 1: Continuous production of citric acid. Bioprocess and
Biosystems Engineering, December 1997, vol. 18, no. 1, p. 1-5.

WIECZOREK, S. and BRAUER, H. Continuous production of citric acid with recirculation of the fermentation broth after product recovery, Part 2: Product recovery and recirculation of the fermentation broth. Bioprocess and Biosystems Engineering, February 1998, vol. 18 , no. 2, p. 75-77.

VENTER, T.; KOCK, J.L.F.; BOTES, P.J.; SMIT, M.S.; HUGO, A. and Joseph, M. Acetate enhances citric acid production by Yarrowia lipolytica when grown on sunflower oil. Systematic and Applied Microbiology, March 2004, vol. 27, no. 2, p. 135-138.

\section{DECLARATION}

The experiments of the present manuscript comply with the currant laws of the country Germany (Institute of Biotechnology 2 of Research Centre Jülich 2 (RCJ); formerly known as Nuclear Research Centre Jülich (KFA), where the experiments were performed. 